\title{
HAEMATOLOGICAL PARAMETERS AND BLOOD CHEMISTRY OF WEST AFRICAN DWARF GOAT TETHERED AT THREE DIFFERENT RADII
}

\author{
Omoniyi Olusei Eniolorunda, Oladipuipo David Olamilusi, Jamiu Adeseun Oyesiji \\ Department of Animal Production, Faculty of Agricultural Production and Renewable Resource, \\ College of Agricultural Sciences, Olabisi Onabanjo University, Ayetoro Campus, \\ Ayetoro, Ogun State, Nigeria \\ olueniolorunda@gmail.com
}

\begin{abstract}
A b s t r a c t: The haematological parameters and blood chemistry of West African Dwarf (WAD) goats tethered at three different radii were carried out for a period of 77 days using eighteen West African Dwarf goats. The animals were allocated into three treatments and each treatment was replicated six times in a completely randomized design. At the commencement, middle and end of the experiment, the data collected were subjected to analysis of variance. Haematological parameters like packed cell volume (PVC), Hb, RBC, WBC and the differentials on treatment effect were not significance $(\mathrm{P}>0.05$ ) while RBC, Mean Corpuscular Volume (MCV), Mean Corpuscular Haemoglobin $(\mathrm{MCH})$ showed a significant $(\mathrm{P}<0.05)$ difference at second collection and Mean Corpuscular Haemoglobin Concentrate (MCHC) showed significant $(\mathrm{P}<0.05)$ difference at the third collection. However, cortisol, glucose, T. protein, BUN, creatinine, AST and ALT as blood chemistry revealed that the results were significantly $(\mathrm{P}<0.05)$ differed with the exception of glucose, T-protein, creatinine, AST and ALT that showed no significance $(\mathrm{P}>0.05)$ at the first, second, second, first and first blood collection period, respectively. Despite, the level of significance, among other parameters, BUN showed no significant $(\mathrm{P}>0.05)$ difference among treatment at all collection of blood periods, some values fell within the normal range of West African Dwarf goats. It is therefore, concluded that tethering animals could be used at a radius of $183 \mathrm{~cm}$ or longer rope length which was more favourable in the study than animals on $91.5 \mathrm{~cm}$ circumference and $0 \mathrm{~cm}$, since the blood studies fell within the normal range which shows that there are at least no pathological conditions between the tethered animals and the free range animals.
\end{abstract}

Key words: haematology; blood chemistry; WAD goat; tethered; radii

\section{ХЕМАТОЛОШКИ ПАРАМЕТРИ И ХЕМИЈА НА КРВТА НА ЗАПАДНОАФРИКАНСКАТА ЏУЏЕСТА КОЗА ПРИВРЗАНА ВО ТРИ РАЗЛИЧНИ РАДИУСИ}

А п с т р а к т: Беше спроведено истражување на хематолошките параметри и хемијата на крвта на осумнаесет западноафрикански џуџести (WAD) кози приврзани во три различни радиуси на движење во траење од 77 дена. Животните беа поделени во три групи, а третманот на секоја група беше реплициран шест пати без каков и да е план. На почетокот, средината и крајот на експериментот собраните податоци беа подложени на анализа на варијација. Хематолошките параметри, како што се PVC, Hb, RBC, WBC, како и разликите во ефектот од третманот не беа значителни (P > 0,05), додека RBC, средниот корпускуларен волумен $(\mathrm{MCV})$ и средниот корпускуларен хемоглобин $(\mathrm{MCH})$ покажаа значителна $(\mathrm{P}<0,05)$ разлика при второто мерење, а средниот корпускуларен хемоглобински концентрат $(\mathrm{MCHC})$ покажа значителна $(\mathrm{P}<0,05)$ разлика при третото мерење. Сепак, резултатите на анализите за кортизолот, глукозата, T-протеинот, BUN, креатининот, AST и ALT како хемиски состојки на крвта значително $(\mathrm{P}<0,05)$ се разликуваа со исклучок на глукозата; Т-протеинот, креатининот, AST и ALT, кои не покажаа никаква значајна $(\mathrm{P}>0,05)$ разлика во првиот, вториот, вториот, првиот и првиот период на прибирање на крвта, соодветно. Но и покрај тоа, нивото на значајност на BUN, меѓy другите параметри, не покажа никаква значајна $(\mathrm{P}>0,05)$ разлика меѓу третманите во сите периоди на прибирање крв, при што некои вредности спаѓаa во нормални граници за западноафриканските џуџести кози. Оттука, беше заклучено дека врзаните животни можат да се користат при радиус на движењето од $183 \mathrm{~cm}$ или 
со поголема должина на јажето, што во студијата се покажало поповолно отколку при радиус на движењето од $91,5 \mathrm{~cm}$ или $0 \mathrm{~cm}$, но бидејќи податоците за хемијата на крвта добиени во оваа студија се движат во нормални граници, може да се заклучи дека во најмала рака не постојат никакви патолошки sostojbi кај врзаните животни и животните кои можат слободно да се движат.

Клучни зборови: хематологија; хемија на крвта; WAD коза; врзана, радиуси

\section{INTRODUCTION}

Goats constitute the largest group of small ruminant livestock in Nigeria totaling about 53.8 million and also constituting 6.2 percent of the World's goat population (FAOSTAT, 2011). Surveys have shown that up to 85 percent of rural households, poor farmers and small-time business people of all age groups and sexes keep goat (FDLPCS, 2007). However, West African Dwarf goats are indigenous to the rainforest zone of Nigeria and have also been reported to do well outside their natural habitat if well managed (Ahamefule et al., 2011). Likewise, the production of WAD goats play very important roles in the economy of the small holder farmers; it is often referred to as the poor man's cow (Aromolaran and Oyebode, 1998). They provide their owners with a vast range of products and services and due to their small size; they are more easily convertible to immediate cash income when compared to cattle and other large ruminants, meat, milk, skins for leather, risk spreading or management and social function such as naming ceremonies, wedding ceremonies and so on (Berhanu et al., 2006, Adane and Girma, 2008).

The Traditional management system practice of goat production is characterized by a free roaming condition where animals search for feed and water. However, this system is becoming impracticable in many parts of the country as a result of high population density and increasing pressure on agricultural lands. Sequel to this, an alternative to fencing which can be used for both large and small ruminants is tethering, where individual animals are tied by the neck, to a stake or a tree, with a rope long enough to allow them freedom to graze and browse at a given radius. However, the life of all flesh is the blood and its usefulness for assessing the health status, chemical evaluation for survey, physicalogical pathological conditions and diagnostic and prognostic evaluation of various types of diseases in animals cannot be over emphasize (Tambuwal et al., 2002, Alade et al., 2005). It also helps in distinguishing normal state form state of stress, which can be maturational, environmental or physical (Aderemi, 2004). Haematological values are widely used to determine systematic relationship and physiological adaptation including the assessment of general health condition of animal as reported by Esonu et al. (2001) and Kamal et al. (2007).

The importance of haematological and biochemical indices of animals cannot be over emphasized as it is well acknowledged (Addass et al., 2010; Obua et al., 2012). Yet, it gives some insight into the production performance potentials of West African Dwarf goats (Kamal et al., 2007). This study was therefore aimed at evaluating the haematological parameters and blood chemistry of West African Dwarf goats tethered at three different radii.

\section{MATERIALS AND METHODS}

\section{Study location}

The experiment was conducted at the Teaching and Research Farm, College of Agricultural Sciences, Olabisi Onabanjo University, Yewa Campus, Ayetoro, Ogun State, Nigeria. The university campus is located in a deciduous/derived savannah zone of Nigeria at latitude $7^{0} 15^{1} \mathrm{~N}$ and longitude $3^{0} 3^{1} \mathrm{E}$. Climate is sub-humid tropical with an annual rainfall of $1,909.3 \mathrm{~mm}$. Rainy season is between early April and late October. Rainfall pattern is bimodal with two peaks in June and September. Maximum temperature varies between $29^{\circ} \mathrm{C}$ during the peak of the wet season and $34^{\circ} \mathrm{C}$ at the onset of the dry season and mean annual relative humidity is $81 \%$ (Onakomaiya et al., 1992).

\section{Preparation of the experimental diets}

The whole cassava root tubers were washed and milled, sundried on large tarpaulin sheets for 5 days to eliminated protozoa and fungi as well as to reduce bacterial contamination to form the whole cassava root meal. Other concentrate formulated meals were groundnut cake, palm kernel cake, rice husk, bone meal, oyster shell, premix and salt. The composition of the experimental diet is shown in Table 1. 
Table 1

\section{Percentage composition of experimental diet fed to animal}

\begin{tabular}{lr}
\hline Ingredient & $\%$ \\
\hline Whole cassava root meal & 43.35 \\
Groundnut cake & 16.08 \\
Palm kernel cake & 26.12 \\
Rice husk & 10.45 \\
Bone meal & 2.00 \\
Oyster shell & 1.00 \\
Premix & 0.5 \\
Salt & 0.5 \\
\hline
\end{tabular}

\section{Housing and animal management}

A total number of 18 WAD goats were purchased in Ayetoro metropolis. Prior to the commencement of the experiment, the animals were acclimatized and dewormed for two week (14 days) against ecto and endo parasite using Ivomec at the rate of $2 \mathrm{ml}$ per $20 \mathrm{~kg}$ body weight. Panicum maximum and whole cassava root meal based diets were offered to the animals. Clean water was also given to the animal ad libitum. During acclimation the animals were observed twice daily between $7.00 \mathrm{hrs}$ and $8.00 \mathrm{hrs}$ and $15.00 \mathrm{hrs}$ and $16.00 \mathrm{hrs}$ for their feeding behavior. After the commencement of the experiment, the forage were offered to the animal by 8 a.m. in the morning and withdrawn at evening before introducing the concentrate to them at 3 p.m. The concentrates offered were measured before giving to the animal but forage and water were offered ad libitum.

\section{EXPERIMENTAL DESIGN}

Animals were allocated to three treatments (designated as T0, T1 and T2) and balanced for weight with 6 animals per treatment in a complete randomized design experiment. The 6 animals on T0 which served as the control were tethered at 0 $\mathrm{cm}$ while those on $\mathrm{T} 1$ and $\mathrm{T} 2$ were tethered to a picket screw with a rope at $91.5 \mathrm{~cm}$ and $183 \mathrm{~cm}$, respectively. Animals on T0 were individually kept to roam freely in a $9 \mathrm{~m}^{2}$ pen. All the animals were offered freshly cut Panicum maximum at 8 a.m. in the morning. Cool and clean water was equally offered ad libitum. Animals on T0, T1 and T2 were thereafter offered with measured quantity of whole cassava root based concentrate. Prior to the morning allocation of forage by 8 a.m., the leftover of concentrate were measured and subtracted from the quantity of feed offered initially at ( 3 p.m.) to obtain the quantity of feed consumed by the animal. The feeding and watering trough were well placed to eliminate wastage but the animals could reach the circumference of the trough without stress. This procedure was repeated till the end of the experiment which lasted 77 days.

\section{Chemical analysis of feeds}

The forage and concentrates used for the study were analyzed by dry matter (DM), crude protein (CP), crude fibre (CF), ash, ether extract (EE), nitrogen free extract (NFE) (AOAC, 2002).

\section{Collection of blood samples}

Each of the goat were bled via jugular vein and $10 \mathrm{ml}$ of blood were collected using hypodermic syringes before feeding at 0 day, 38 days and 77 days of the feeding trial. $5 \mathrm{ml}$ of blood was drawn into ethyl diamine tetraacetic acid (EDTA) bottle for haematology; the remaining $5 \mathrm{ml}$ was deposited in anticoagulant free plastic tubes and allowed to clot at room temperature for biochemical indices.

The PCV (packed cell volume) was measured using the micro-haematocrit method. Haemoglobin concentration was measured using Sahl's (acid haematin) method (Benjamin, 1978). RBC (red blood cell), WBC (white blood cell) and the WBC differential counts, i.e. the lymphocytes, heterophils, eosinophils and monocytes were measured with the aid of Neubauer counting chamber (haemocytometer). Plasma glucose was measured in fluoride oxalate using the enzymatic glucose oxidase method (Bauer et al., 1974). The MCV (mean corpuscular volume), $\mathrm{MCH}$ (mean corpuscular haemoglobin) and $\mathrm{MCHC}$ (mean corpuscular haemoglobin concentration) values were calculated from PCV, $\mathrm{Hb}$ and $\mathrm{RBC}$ values (Jain, 1993). Total serum protein was measured in serum for individual animal using the biuret method. Serum creatinine was determined using the principle of Jaffe reaction as described (Bonsnes et al., 1945), urea (Tietz, 1970). The activity of the enzymes alanine transaminase (ALT) and aspartate transaminase (AST) was measured using the method of Reitman and Frankel (1957). 


\section{STATISTICAL ANALYSIS}

Data collected from the investigated parameters were subjected to the analysis of variance in completely randomized design using the procedure of SAS (2002).

\section{RESULTS AND DISCUSSION}

The result of chemical composition (100\% DM) of Panicum maximum and concentrate diet fed to WAD goat are presented in Table 2. The result of proximate analysis for Panicum maximum in this study differed slightly from that obtained by Yusuf et. al. (2010) which contained $71.29 \%$ dry matter (DM) with crude protein (CP), $11.25 \%$ ash, $3.07 \%$ either extract, $25.18 \%$ nitrogen free extract (NFE). The difference in values obtained might due to season of harvest or types of soil.

Table 2

Chemical composition of forage and concentrate fed to the experimental animals

\begin{tabular}{lcc}
\hline Composition & Panicum maximum & Concentrate \\
\hline Dry matter & 95.88 & 91.44 \\
Crude protein & 8.14 & 18.01 \\
Crude fibre & 10.36 & 10.25 \\
Ether extract & 22.27 & 5.00 \\
Ash & 2.70 & 4.48 \\
NFE & 56.54 & 62.26 \\
\hline
\end{tabular}

The haematological parameters of West African dwarf goats tethered at three different radii showed in Table 3. There was no significant $(\mathrm{P}>$ $0.05)$ differences in PCV, HB, WBC and their differentials during the collection period except $\mathrm{RBC}$ which shows significant difference $(\mathrm{P}<0.05)$ in $\mathrm{T} 2$ at the second collection than animal in T0, but similar to that of $\mathrm{T} 1$ which indicates $\mathrm{T} 2>\mathrm{T} 1>\mathrm{T} 0$, respectively. There was significantly lower $(\mathrm{P}<0.05)$ MCV values in T2 while the values in $\mathrm{T} 1$ compared favourably to $\mathrm{T} 0$ at the second collection. The $\mathrm{MCH}$ also follow this same trend at the second collection. There was no significant $(\mathrm{P}>0.05)$ difference among treatments at the first and third collection periods, but $\mathrm{T} 2$ shows significantly higher $(\mathrm{P}<0.05)$ in $\mathrm{MCHC}$ recorded values when compared to $\mathrm{T} 1$ and T0 has the lowest values.
Table 3

Effects of treatments on haematological profile of experimental animals tethered at different radii

\begin{tabular}{|c|c|c|c|c|c|}
\hline Parameters & $\begin{array}{l}\text { Collection } \\
\text { period }\end{array}$ & T0 & $\mathrm{T} 1$ & $\mathrm{~T} 2$ & SEM \\
\hline \multirow{3}{*}{$\begin{array}{l}\text { Packed cell } \\
\text { volume }(\%)\end{array}$} & 1 & 51.29 & 49.17 & 52.50 & 6.17 \\
\hline & 2 & 51.25 & 51.67 & 50.00 & 4.91 \\
\hline & 3 & 45.00 & 50.00 & 50.00 & 6.48 \\
\hline \multirow{3}{*}{$\begin{array}{l}\text { Haemoglobin } \\
\text { conc. }(\mathrm{g} / \mathrm{dl})\end{array}$} & 1 & 13.13 & 12.77 & 13.70 & 1.58 \\
\hline & 2 & 14.25 & 14.35 & 14.13 & 1.35 \\
\hline & 3 & 12.25 & 13.95 & 14.50 & 1.88 \\
\hline \multirow{3}{*}{$\begin{array}{l}\text { Red blood cell } \\
\left(\times 10^{6} \mu \mathrm{l}\right)\end{array}$} & 1 & 5.15 & 5.38 & 6.40 & 1.10 \\
\hline & 2 & $5.53^{\mathrm{b}}$ & $5.97^{\mathrm{ab}}$ & $6.98^{\mathrm{a}}$ & 2.85 \\
\hline & 3 & 5.90 & 5.68 & 6.70 & 1.64 \\
\hline \multirow{3}{*}{$\begin{array}{l}\text { White blood cell } \\
\left(\times 10^{3} \mu \mathrm{l}\right)\end{array}$} & 1 & 5.58 & 5.53 & 5.58 & 1.39 \\
\hline & 2 & 5.75 & 5.57 & 5.03 & 1.65 \\
\hline & 3 & 5.20 & 5.53 & 5.83 & 1.66 \\
\hline \multirow{3}{*}{$\begin{array}{l}\text { Lymphocyte } \\
(\%)\end{array}$} & 1 & 61.25 & 62.50 & 63.75 & 9.74 \\
\hline & 2 & 62.50 & 65.83 & 65.00 & 7.27 \\
\hline & 3 & 65.00 & 67.50 & 63.75 & 7.00 \\
\hline \multirow[t]{3}{*}{ Neutrophils (\%) } & 1 & 37.50 & 36.67 & 36.25 & 8.59 \\
\hline & 2 & 37.50 & 34.17 & 35.00 & 7.27 \\
\hline & 3 & 35.00 & 31.67 & 35.00 & 8.27 \\
\hline \multirow[t]{3}{*}{ Eosinophils (\%) } & 1 & 1.25 & 0.83 & 0.00 & 2.23 \\
\hline & 2 & 0.00 & 0.00 & 0.00 & 0.08 \\
\hline & 3 & 1.25 & 0.83 & 1.25 & 2.33 \\
\hline \multirow[t]{3}{*}{ Monocytes (\%) } & 1 & 0.00 & 0.00 & 0.00 & 0.00 \\
\hline & 2 & 0.00 & 0.00 & 0.00 & 0.00 \\
\hline & 3 & 0.00 & 0.00 & 0.00 & 0.00 \\
\hline \multirow[t]{3}{*}{ Basophil (\%) } & 1 & 0.00 & 0.00 & 0.00 & 0.00 \\
\hline & 2 & 0.00 & 0.00 & 0.00 & 0.00 \\
\hline & 3 & 0.00 & 0.00 & 0.00 & 0.00 \\
\hline \multirow[t]{3}{*}{$\mathrm{MCV}(\mathrm{fl})$} & 1 & 86.33 & 93.43 & 84.93 & 22.26 \\
\hline & 2 & $94.75^{\mathrm{a}}$ & $88.88^{\mathrm{ab}}$ & $72.58^{\mathrm{b}}$ & 14.40 \\
\hline & 3 & 78.55 & 90.43 & 82.60 & 30.79 \\
\hline \multirow[t]{3}{*}{$\mathrm{MCH}(\mathrm{pg})$} & 1 & 24.35 & 24.27 & 22.13 & 6.32 \\
\hline & 2 & $27.13^{\mathrm{a}}$ & $24.68^{\mathrm{ab}}$ & $20.35^{\mathrm{b}}$ & 3.64 \\
\hline & 3 & 21.45 & 25.27 & 19.48 & 7.00 \\
\hline \multirow[t]{3}{*}{ MCHC (pg) } & 1 & 25.60 & 26.00 & 26.13 & 1.30 \\
\hline & 2 & 27.85 & 27.82 & 28.25 & 1.73 \\
\hline & 3 & $27.18^{b}$ & $27.97^{\mathrm{ab}}$ & $29.00^{\mathrm{a}}$ & 1.38 \\
\hline
\end{tabular}


The values obtained at T2 (50\%) in this study were lower than the values recorded by Daramola et al., 2005. But similar to the values 36-50\% for clinical healthy WAD goats and sheep respectively reported by Taiwo and Ogunsola (2003); www.infolona.com (2013). The very initial value (52\%) of PCV recorded for T2 suggested dehydration in the animal while normal at the third collection. The haemoglobin concentration range in this study follow the same trend with the range of 7-15 g/dl reported for clinically healthy WAD goats documented by goatlink.com (2009), also reported by Daramola et al., 2005. This suggests that the animals were not anaemic because the $\mathrm{Hb}$ values were not lower than $7 \mathrm{~g} / \mathrm{dl}$ and neither could they be said to have tumor and disorder of the bone marrow. In contract to Ogunleke et al. (2014) that WAD goats seem to possess a relatively high $\mathrm{Hb}$ and this is advantageous in term of oxygen carrying of the blood. The highest value $\left(6.98 \times 10^{6} \mu \mathrm{l}\right)$ was found higher than values range between 4.5 and 6.0 documented as normal range by infolona.com, 2013, this was similar to the $\mathrm{RBC}$ recorded in the present study. But was not in agreement with $\mathrm{RBC}$ counts within the range of 9.2-13.5 $\times 10^{6} / \mu 1$ reported for West African dwarf goats by Tambuwal et al. (2002) and 9.9$18.7 \times 10^{6} / \mu 1$ reported by Taiwo et al. (2003). Thus, lower in RBC count maybe attributable to stress (splenic contraction), hydration status, hormonal influences, dietary and nutritional differences, adaptations to a desert environment or adaptation to a high mountain environment (Borijesson et al., 2000). The total WBC count was at normal range value 5$13 \times 10^{3} \mathrm{ml}$ as reported by Okonkwo et al. (2011) which illustrated a damage or destruction of tissue if higher than the normal value and if lower than normal it may indicate disease of the liver or spleen (www.infolona.com, 2013). The WBC values observed in this study were higher than the values reported by Tambuwal et al. (2002) for Red Sokoto goat, by Taiwo and Ogunsanmi (2003) for West African dwarf sheep and by Daramola et al. (2005) for West African dwarf goats.

Lymphocyte and neutrophils values obtained in this study throughout the collection period of blood in the experiment correspond with the normal range value of $50-70 \%$ and $30-40 \%$, respectively (reported by www.goatlink.com, 2009). Moreover, Ikhimioya and Imasuen (2007) reported values of $56-86 \%$ and $32-41 \%$ of lymphocytes and neutrophils respectively, in WAD goats. Elevated levels of lymphocyte value may indicate an active viral infection and a depressed level may indicate an exausted immune system. Eosinophila, monocytes and basophils obtained in this study fell between the normal range of $0-10 \%, 0-6 \%$ and $0-3 \%$. respectively reported by Nse Abassi et al. (2014) in sheep. A level above normal range may indicate allergic response while a low count is normal for eosinophils and basophils. Elevated level of monocyte count is seen in tissue breakdown while low levels are indicative of a state of health. Mean corpuscular haemoglobin obtained in this study were comparable among treatments at the first collection but not well compared at the second collection period of blood. However, value of $\mathrm{MCH}$ was later compared well among treatments. $\mathrm{MCH}$ values obtained fell within the normal range of 27-32 pg reported by infolona.com (2013). Elevated level of MCH count indicates nutritional deficiency while low level are indication of water with high lead content.

Mean corpuscular haemoglobin concentrate at the first and second collection of blood samples shown no significant difference $(\mathrm{P}>0.05)$ between treatments but showed higher significant level at T2 during the third collection of blood sample. Although, treatments did not significantly influence the $\mathrm{MCHC}$ at the last blood collection. The higher significant in T2 is compared to the value obtained for normal range $31 \mathrm{~g} / \mathrm{dl}$ reported by Nse Abassi et al., (2014) of sheep. Elevated level of MCHC count is due to indication of haemolytic anaemia while low levels are indicative rheumatoid arthritis and lead poisoning.

The blood chemistry of West African dwarf goats tethered at three different radii showed in Table 4 . There were significant $(\mathrm{P}<0.05)$ difference in values obtained for the second and third collection periods, while no significant $(\mathrm{P}>0.05)$ in $\mathrm{T} 0$, $\mathrm{T} 1$ and $\mathrm{T} 2$ at the initial blood collection. The cortisol level shows significant $(p<0.05)$ difference throughout the collection period. Although, at the third collection, T0 has the least values when compared to $\mathrm{T} 2$ and $\mathrm{T} 1$, respectively. The $\mathrm{T}$. protein shows no significant difference at the second collection, while $\mathrm{T} 0$ tends to have the highest value and $\mathrm{T} 1$ and $\mathrm{T} 2$ follow this trend. There was no significant difference $(\mathrm{P}>0.05)$ in BUN throughout the collection period. The creatinine has significant difference in the first and third collection period, in which $\mathrm{T} 0$ and $\mathrm{T} 2$ having similar values while $\mathrm{T} 1$ is the lowest. The AST and ALT have no significant difference $(\mathrm{P}>0.05)$ at the first collection period, but show difference at the second and third collection at all the treatments considered. 
Table 4

Effects of treatments on blood chemistry of experimental animals tethered at different radii

\begin{tabular}{|c|c|c|c|c|c|}
\hline Parameters & $\begin{array}{c}\text { Collection } \\
\text { period }\end{array}$ & T0 & $\mathrm{T} 1$ & $\mathrm{~T} 2$ & SEM \\
\hline \multirow{3}{*}{$\begin{array}{l}\text { Glucose } \\
\text { (mg/dl) }\end{array}$} & 1 & 54.23 & 49.30 & 56.18 & 5.96 \\
\hline & 2 & $65.63^{a}$ & $66.65^{\mathrm{a}}$ & $59.78^{\mathrm{b}}$ & 4.37 \\
\hline & 3 & $52.93^{\mathrm{b}}$ & $58.83^{\mathrm{ab}}$ & $65.03^{\mathrm{a}}$ & 8.31 \\
\hline \multirow{3}{*}{$\begin{array}{l}\text { Cortisol } \\
(\mathrm{nmol} / \mathrm{l})\end{array}$} & 1 & $54.30^{\mathrm{b}}$ & $57.85^{\mathrm{a}}$ & $56.75^{\mathrm{ab}}$ & 2.49 \\
\hline & 2 & $53.23^{\mathrm{c}}$ & $73.57^{\mathrm{a}}$ & $63.90^{\mathrm{b}}$ & 4.31 \\
\hline & 3 & $51.78^{\mathrm{b}}$ & $63.30^{\mathrm{a}}$ & $60.90^{\mathrm{a}}$ & 4.90 \\
\hline \multirow{3}{*}{$\begin{array}{l}\text { T. protein } \\
\text { (g/l) }\end{array}$} & 1 & $54.23^{\mathrm{b}}$ & $59.78^{\mathrm{a}}$ & $60.13^{a}$ & 3.62 \\
\hline & 2 & 66.65 & 66.78 & 71.03 & 4.21 \\
\hline & 3 & $71.33^{\mathrm{a}}$ & $65.97^{b}$ & $66.25^{\mathrm{b}}$ & 3.39 \\
\hline \multirow{3}{*}{$\begin{array}{l}\text { BUN } \\
(\mathrm{mg} / \mu \mathrm{l})\end{array}$} & 1 & 22.38 & 20.55 & 18.63 & 4.01 \\
\hline & 2 & 27.98 & 32.88 & 31.23 & 8.26 \\
\hline & 3 & 35.38 & 34.75 & 35.38 & 3.17 \\
\hline \multirow{3}{*}{$\begin{array}{l}\text { Creatinine } \\
(\mathrm{mg} / \mathrm{dl})\end{array}$} & 1 & $0.85^{\mathrm{a}}$ & $0.92^{\mathrm{ab}}$ & $1.00^{\mathrm{a}}$ & 0.21 \\
\hline & 2 & 1.23 & 1.23 & 1.23 & 0.21 \\
\hline & 3 & $1.28^{\mathrm{a}}$ & $1.07^{\mathrm{b}}$ & $1.18^{\mathrm{ab}}$ & 0.12 \\
\hline \multirow[t]{3}{*}{ AST (i $\mu / 1)$} & 1 & 96.60 & 92.68 & 88.13 & 18.89 \\
\hline & 2 & $138.73^{\mathrm{a}}$ & $100.97^{b}$ & $114.03^{\mathrm{ab}}$ & 27.35 \\
\hline & 3 & $103.45^{\mathrm{a}}$ & $103.85^{\mathrm{a}}$ & $96.10^{\mathrm{b}}$ & 5.65 \\
\hline \multirow[t]{3}{*}{ ALT (i $\mu / 1)$} & 1 & 21.00 & 15.00 & 13.50 & 6.40 \\
\hline & 2 & $20.25^{\mathrm{a}}$ & $12.50^{\mathrm{ab}}$ & $10.75^{\mathrm{b}}$ & 6.78 \\
\hline & 3 & $24.48^{\mathrm{a}}$ & $16.13^{b}$ & $10.75^{\mathrm{b}}$ & 5.07 \\
\hline
\end{tabular}

$\mathrm{abc}$ means the same row with different superscript are significantly $(\mathrm{P}<0.05)$ different

The glucose level values in this present study 52.93 and $65.03 \mathrm{mg} / \mathrm{dl}$ across the treatments at the third collection period fell at the normal range value of $48-76 \mathrm{mg} / \mathrm{dl}$ documented by goatlink.com (2009). This indicates that the animals tethered are also found in good health condition as the blood glucose test is ordered to measure the amount of glucose in at the time of blood collection. Kaneko (1997) reported that when the blood glucose is higher or lower than the normal condition it referred to as hyperglycaemia or hypoglycaemia, respectively. Also, ensues high glucose level could cause several physiological stress or problem such as frequent urination, excessive thirst while low level of glucose could cause weight loss, blurry vision, unthrifty state. Total protein recorded in the study meets the stated requirement recorded by Tambuwal et al. (2002), which is reported for Red Sokoto goat. The lower values for the total protein could be probably due to the fact that animals used some of the protein content to replenish the tissues and other needed functioning of the body. Also, as reported by Jain (1986) that serum protein are important in osmotic regulation, immunity and transport of several substances in the animal body. The values ranged from $18.63-35.38 \mathrm{mg} / \mathrm{dl}$ were slightly lower than the value $(37.30 \mathrm{mg} / \mathrm{dl})$ reported by Ikhimioya and Imasuen (2007), but higher than the normal range values $(12.6-28 \mathrm{mg} / \mathrm{dl})$ for goat documented by goatlink.com (2009). Higher values recorded in this study could probably due to persistent hypoglycaemia since according to Daramola et al. (2014) that catabolic activity is increased for gluconeogenesis thus resulting in higher serum urea level. Also, higher urea level in the blood signifies excessive breakdown of protein in the liver is unable to metabolize the excessive ammonia produced from protein catabolism and also impaired excretion through the urine from the kidney (Bell et al., 2005).

The values recorded for creatinine in this study fell within the normal range value $(0.9-1.8 \mathrm{mg} / \mathrm{dl})$ documented by goatlink.com (2009). Creatinine is a non proteinous substance formed in the metabolism of muscles and cleared from plasma at approximately the glomerular filtrate rate since it is readily excreted by kidney elevations which do not occur until kidney damage is quite severe. So, the result shows that tethering did not affect the animals in all treatments. The monitored activities of the enzymes aspartate transaminase (AST) and alanine transaminase (ALT) in this study were at the recorded values 66-230 iu/l and 10-40 iu/l respectively as documented by infolona.com (2013). The importance of these enzymes plays vital role in processing proteins, reflection of a balance between synthesis and their releases as a result of the different physiological processes in the body. Moreover, they are also responsible for the synthesis of non-essential amino acids through the process known as transamination according to Carola et al. (1990). However, if the levels are higher than normal; it causes liver damage and gallbladder disease. An increase in these enzymes may be cause by malfunctioning of the liver.

\section{CONCLUSION}

According to the results showed on the haematology and blood chemistry of West African dwarf goats between tethered animals and animals on free range, it was revealed that were minimal adverse 
efects of tethering on haematological parameters and blood chemistry on T2 $(183 \mathrm{~cm})$ compared to $\mathrm{T} 1$ and $\mathrm{T} 0$. The values obtained for blood studies fell within the normal value range but animals on $\mathrm{T} 2$ showed a better physiological status, due to similarities that exist between the tethered animals and free range animals in terms of blood parameters test. It is therefore recommended with the conclusions made above that tethering of animals could be used at a radius of $183 \mathrm{~cm}$ or longer rope length which was more favourable in the study than animals on $91.5 \mathrm{~cm}$ circumference and $0 \mathrm{~cm}$. So, the landless farmers and the landless urban dwellers can tether animals at $183 \mathrm{~cm}$ or more in as much the animals are supplied with concentrate diet rich in $18.01 \%$ $\mathrm{CP}$.

\section{REFERENCE}

[1] Adane, Y., Girma, A. (2008): Economic and marketing systems in Ethiopia: Characteristics significance of sheep and goats. In: Alemu, teristics and strategies for improvement. IPMS Y., Markel, R.C. (Eds.) Sheep and Goat (Improving Productivity and Market Success) of Production Handbook for Ethiopia.

[2] Addass, P.A., Midau, A. and Babale, D.M. (2010): Haemato-biochemical findings of indigenous goats in Mubi, Adamawa State, Nigeria. J. Agric Sci. 6, 14-16.

[3] Aderemi, F.A (2004): Effects of replacement of wheat bran with cassava root sieviate supplemented of unsupplemented with enzyme on the haematology and serum biochemistry of pullet chicks. Trop. J. Animal Sci. 7, 147-153.

[4] Ahamefule, F. O., Odilinye, O. and Nwachukwu, E. N. (2011): Comparative evaluation of milk yield and composition of Red Sokoto and West African Dwarf does in a humid hot environment. Proceedings of the $36^{\text {th }}$ Annual Conference of the Nigerian Society for Animal Production. 13 - 16th March, 2011, Abuja, Nigeria, pp. 513 - 515.

[5] Alade, A. A., Bambose, A. M., Ogutona, E. B. and Fanimo, A. O. (2005): Heamatological parameters, serum metabolites carcass characteristic of weaner rabbits fed yam feel meal diets. Proceedings of 10th Annual Conference of Animal Science Association of Nigeria Dairo, F.A.S. So. K Fajemilehin and G.E Onobi (Eds) held on 12-15 September at University of Ado-Ekiti, Nigeria. pp. 280-282.

[6] Aromolaran, A.B. and Oyebode, O.A. (1998): A socioeconomic investigation into the goat product system in selected area in Ogun State, Nigeria. Proceedings of the $26^{\text {th }}$ Annual conference of the Nigeria Society of Animal Production, March $18^{\text {th }}-22^{\text {nd }}, 2001$.

[7] Association of Official Methods of Analysis (2002). Association of Official Analytical Chemist. (18 ${ }^{\text {th }}$ Edition). Washington D. C.

[8] Bauer T. D., Ackermann P. G., Toro G. (1974): Methods in Clinical Chemistry. Clinical Laboratory Methods. The CV Mosley Company, Saint Louis. 946.

[9] Bell, R. D., Sinclair, R. J., and Keyl, M. J. (2005): Proceedings of the Society of Experiemental and Biological Medicine, pg. 109, 139.
[10] Benjamin M. M. (1978): Outline of Veterinary Clinical Pathology, 2nd edition. Iowa State University Press. Iowa, U.S.A. pp. 35-105.

[11] Berhanu, G., Adane, H. and Kahsay, B. (2006): Feed marketing in Ethiopia: Results of rapid market appraisal.

[12] Bonsnes R. W, Taussky H. H. J. (1945): Determination of creatinine in plasma and urine. J. Biochem., 58, pp. 581589.

[13] Borjesson, D. L., Christopher, M. M. and Boyce, W. M. (2000): Biochemical and Hematologic Reference Intervals for Free-Ranging Desert Bighorn Sheep. Journal of Wildlife Diseases, 36, 294-300. http://dx.doi.org/10.7589/0090-3558-36.2.294

[14] Carola, R., Harley, J. P. and Noback, C. R. (1990): Human anatomy and physiology. McGraw-Hill Inc. USA. 925 p.

[15] Daramola J. O., Adeloye A. A., Fatoba T. A, Soladoye A.O. (2014): Haematological and biochemical parameters of West African Dwarf goats. Liv. Res. Rural Dev; 17. Retrieved May 28, 2014, from Available: http://www.lrrd.org/lrrd17/8/dara17095.htm.

[16] Daramola, J. O., Adeloye, A. A., Fatoba, T. A. and Soladoye, A. O. (2005): Haematological and biochemical parameters of West African goats. Livestock Research for Rural Development, 17 (8). Retrieved from: http://www.cipav.org.co

[17] Esonu, B. O., Emenalom, O. O., Udedibie, A. B. I., Herbert, U., Ekpor, C. F., Okolie, I. C. and Iheukwumere, F.C. (2001): Performance and Blood Chemistry of Weaner Pigs Fed Raw Mucuna (Velvet Bean). Tropical Animal Production Investigations, 4, 49-54.

[18] FAOSTAT (2011): Food and Agricultural Organization of the United Nations (available at http://faostat.fao.org/ default.aspx; accessed 19 July 2011).

[19] FDLPCS, (2007): Federal Department of Livestock and Pest Control Services. FLDPCS Nigerian. Livestock Resources. National Synthesis, $440 \mathrm{p}$.

[20] Ikhimioya, I., and Imasuen, J. A. (2007): Blood profile of West African dwarf goats fed Panicum maximum supplemented with Afzelia Africana and Newbouldia laevis. Pak. J. Nut., 6 (1), 79-84.

[21] Jain N. C. (1993): Essentials of Veterinary Haematology. Lea and ferbeiger, Pennsylvania, U.S.A. 7.

[22] Jain, N. C. (1986): Schalms Veterinary Haematology. $4^{\text {th }}$ ed., Lea and Febiger, Philadelpha, USA.

[23] Kamal Shah M., Khanm A., Rizvi, F., Siddique, M. and Sadeeq-ur-rehman. (2007): Effect of cypermethrin on clinico-haematological parameters in rabbits. Pauistan vet. J., 27 (4), 171-175.

[24] Kaneko, J. (1997): Clinical Biochemistry of Domestic Animals. $5^{\text {th }}$ edition, Academic Press, New York, pp 932.

[25] Nse Abasi, N. E., Mary E. W., Uduak A. and E. E. A. Offiong (2014): Haematological Parameters and Factors Affecting their Values, Vol. 2, Issue 1, 37-47.

[26] Obua, B. E., Amaechi, N. and Osodeke, S. (2012): Comparative evaluation of haematological profile of West African dwarf and Red Sokoto goats reared in Humid South Eastern Nigeria. Int'l Journal of Agric and Rural Dev. 15 (3), 1190-1197.

[27] Ogunleke F. O., Ajayi, F. T., Morakinyo, O. A., and Saka, A. A. (2014): Performance and blood profile of West African dwarf goat fed concentrate supplement containing 
varying levels of corncobs. American Journal of Experimental Agriculture, 4 (12): 1861-1868.

[28] Okonkwo, J. C., Okonkwo, I. F. and Ebuh, G. U. (2011): Effects of breed, sex and source within breed on the haematological parameters of the Nigerian goats. Online Journal of Animal and feed Research. 1 (1), 8-13.

[29] Onakomaiya, S. O., Oyesiku, K. A., and Jegede, S. J. (1992): Ogun State in Maps. First ed. Rex. Charles Publication, Ibadan.

[30] Reitman, S. and S. Frankel (1957): A calorimetric method for determination of serum glutamic oxaloacetic transaminase serum glutamic pyruvic ytansaminase. Am. J. Clin. Pth., 28, 56-63.

[31] Taiwo V. O. and Ogunsanmi, A. O. (2003): Haematology plasma, whole blood and erythrocyte biochemical values of clinically healthy captive-reared grey duiker (Sylvicapra grimmia) and West African dwarf sheep and goats in
Ibaan, Nigeria. Israel J. Vet. Med., Retrieved from http://www.isrvma.org/article/58_2_3.htm

[32] Tambuwal F. M, Agale, B. M. and Bangana, A. (2002): Haematological and biochemical values of apparently healthy Red Sokoto goats. Proceedings of 27th Annual conference Nigerian Society of Animal Production (NSAP) March 17-21, 2002 FUTA, Akure.

[33] Tietz, N. W. (1970): Fundamentals of Clinical Chemistry. W. B. Sanders \& Co., Philadelphia, USA, p. 718.

[34] www.goatlink.com/content/view/204/194/, 2009

[35] www.infolona.com/health_personal_and_emergency_care/blood_test_results_explained/find, 2003.

[36] Yusuf, M. A., Kumar, D., Rajwanshi, R., Strasser, R. J., Tsimilli Michael, M., Govindjee, and Sarin, N. B. (2010): Overexpression of tocopherol methyl transferase gene in transgenic Brassica juncea plants alleviated abiotics stress: physiological and chlorophyll fluorescence measurements. Biochim. Biophys. Acta, 1797, 1428-1438. 